\title{
Obituary
}

\section{Mark Anthony Smith (1965-2010): Visionary, Alzheimer Researcher, and Editor-in-Chief of the Journal of Alzheimer's Disease}

\author{
George Perry and Xiongwei Zhu
}

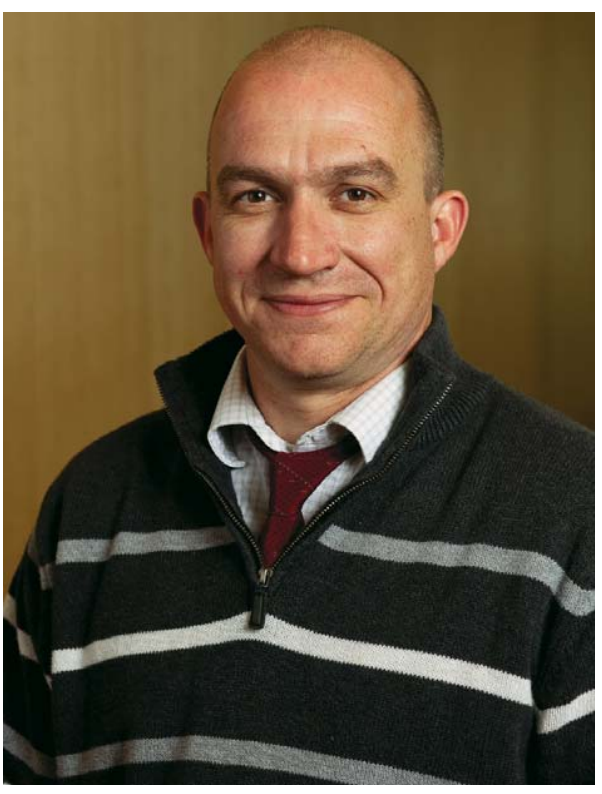

19 December, the date of Alois Alzheimer's death and now that of Mark Smith's. Both, in a short time, defined their field. Alzheimer created the mind-body connection by discovering the cellular pathology of the most common form of dementia, laying the foundation for modern neurology and psychiatry. Smith's efforts were radical and foundational in the same tradition as Alzheimer's, for Smith was the first proponent of Alzheimer's disease (AD) being governed by the laws of biology. While he is most known for questioning the amyloid cascade hypothesis [1], fundamentally he had a distrust of any mechanism that did not rely on evolutionary adaptation for successful aging. Amyloid- $\beta$ (A $\beta)$, tau, oxidative stress, and other mechanisms recapitulate the response of the brain to injury: trauma and aging are both met by these same responses defining AD. Mark's contributions span from defining oxidative stress, cell cycle reentry of neurons, gonadotropins, mitochondria, questioning the amyloid cascade hypothesis, and beyond. He was the most prolific author in AD research over the past 10 years, and the fifth most cited [2]. In addition, he won numerous awards, including the Jordi Folch-Pi Award from the American Society for Neurochemistry, Outstanding Investigator Award from the American Society for Investigative Pathology, Denham Harman Research Award from the American Aging Association, Zenith Award from the Alzheimer's Association, Hermann-Esterbauer Award from the HNE Society, and the Goudie Lecture and Medal from the Pathological Society of Great Britain and Ireland. Additionally, Mark was a fellow of the American Association for the Advancement of Science, American Aging Association, Royal Society of Medicine, and the Royal 
College of Pathologists as well as Daland Fellow of the American Philosophical Society.

His greatest pride was service, ranging from Editorin-Chief of this journal, Executive Director of the American Aging Association, organizer of numerous meetings, participant in many National Institutes of Health, Veteran's Administration, and other grant reviews, and member of over 200 editorial boards. Mark simply could not say no, in his field or to the university, where he was President of the American Association of University Professors, and head of the faculty council at the School of Medicine at Case. It is no surprise that now several societies have either named their own rising investigator awards after Mark, or dedicated meetings, books, and journal issues to his memory. The outpouring of remembrance from AD researchers throughout the world has been astounding, so many saying that Mark's courage to deliver a message as he saw it as an inspiration in their own lives (http://www.j-alz.com/marksmith.html).

Mark's meteoric rise in the mid-1990s was as much marked by his innovative thoughts, exceptional enthusiasm, and communication skills as his unlimited giving to collaborators and coworkers. When he found and defined the first oxidative modifications of $\mathrm{AD}$ pathology, pyrraline and pentosidine [3], and the first oxidative response protein induced, heme oxygenase [4], he revolutionized the field, advancing leaps and bounds from poorly defined changes that are tangentially related to oxidative modification; namely lipofuscin, and protein insolubility. Mark understood oxidative stress was not the end but an opening into the beginning of $\mathrm{AD}$.

Owing to his originality, his efforts were concentrated on connecting $\mathrm{AD}$ to biology, leading to the two-hit hypothesis [5] and other theories, which all focused on the pleotropic threshold between pathology and physiology. The miracle of AD is that neurons filled with tau and in an environment inundated by $A \beta$ and can live for decades. He proposed that $A \beta$ forms which are in dynamic equilibrium, along with tau and numerous other changes, were in fact critical homeostatic responses to AD rather than the cause. This was the foundation of Mark's dissatisfaction with the $\mathrm{A} \beta$, tau, and other pathology-based theories; his focus on biology as the route to understand and reverse disease. Mark's ideas explain the failure of cures of chronic disease contrasted with acute disease, or of diseases of balance versus those of imbalance. Indeed, it is not surprising that Mark suggested over a decade ago the failure of the $A \beta$ vaccine [6], which he elegantly described as disturbing the balance of a critical response to the underlying pathogenesis of $\mathrm{AD}$. His dogma persists today, as no disease mechanism clearly indicts monomers, dimers, oligomers, or other $A \beta$ forms. He envisioned that only working with the biology to modulate the response of aging and restoring physiological balance would offer the hope of more years of health.

That Mark was the originator of a novel view of disease is a reflection of his upbringing, because he was tied to family values of hard work and honesty learned from his coal miner father and enjoyed the love and support of his mother. His focus was always what he could give to those affected by disease, or to those studying and working with him, rather than personal benefit. Mark's contributions continue to inspire our efforts to go forward.

Mark leaves a science family that spans all but two continents (http://academictree.org/alzheimers/ peopleinfo.php?pid=9563). We, along with all of those he touched, will continue to be inspired by Mark's courage to trust in his own science, by his creativity in developing novel hypotheses, and by his charisma, which allowed his ideas to be heard and understood.

\section{REFERENCES}

[1] Joseph J, Shukitt-Hale B, Denisova NA, Martin A, Perry G, Smith MA (2001) Copernicus revisited: amyloid beta in Alzheimer's disease. Neurobiol Aging 22, 131-146.

[2] Sciencewatch.com, Special Topic: Alzheimer's Disease > Top 20 Authors, http://sciencewatch.com/ana/st/alz2/authors/, Accessed March 1, 2011.

[3] Smith MA, Taneda S, Richey PL, Miyata S, Yan SD, Stern D, Sayre LM, Monnier VM, Perry G (1994) Advanced Maillard reaction end products are associated with Alzheimer disease pathology. Proc Natl Acad Sci U S A 91, 5710-5714.

[4] Smith MA, Kutty RK, Richey PL, Yan SD, Stern D, Chader GJ, Wiggert B, Petersen RB, Perry G (1994) Heme oxygenase-1 is associated with the neurofibrillary pathology of Alzheimer's disease. Am J Pathol 145, 42-47.

[5] Zhu X, Raina AK, Perry G, Smith MA (2004) Alzheimer's disease: the two-hit hypothesis. Lancet Neurol 3, 219-226.

[6] Perry G, Nunomura A, Raina AK, Smith MA (2000) Amyloidbeta junkies. Lancet 355, 757 . 